\title{
Linking entrepreneurial orientation and managerial capacity to performance in dairy farms
}

\section{Orientação empreendedora e capacidade gerencial - impactos no desempenho de propriedades com bovinos de leite}

Marina Daneluz ${ }^{1}$ (D), Mario Duarte Canever² (D), Helenice González de Lima³ (D), Rogerio Folha Bermudes² (D), Gabrielito Rauter Menezes² (1)

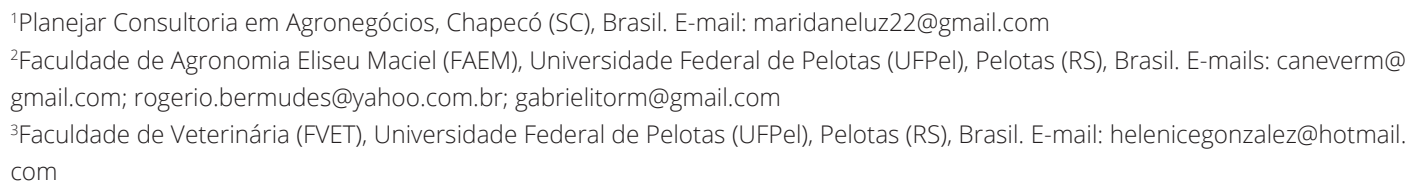

How to cite: Daneluz, M., Canever, M. D., Lima, H. G., Bermudes, R. F., \& Menezes, G. R. (2022). Linking entrepreneurial orientation and managerial capacity to performance in dairy farms. Revista de Economia e Sociologia Rural, 60(3), e229910. https://doi.org/10.1590/1806-9479.2021.229910

\begin{abstract}
The main objective of the study is to develop and test a model that emphasizes the relationship between entrepreneurial orientation (EO) and managerial capacity (MC) to the performance of dairy farms. This article also examines the effect of these variables on performance expectations as well as the succession planning of farms. Cross-sectional data were collected out of a sample of 158 dairy farmers in 2017 in Brazil. A path analysis approach has been applied to validate the hypothesized model. Results show that between EO dimensions, innovativity has the greatest impact on performance as well as on MC. MC is not significantly related to the current performance on dairy farms, but it is so to the performance expectation, which in turn has an impact on the succession planning of farms. The age of the farmers moderates the relations hypothesized in the model, especially between innovativity, proactivity, and MC in the farms' performance.
\end{abstract}

Keywords: entrepreneurial orientation, managerial capacity, dairy farmers, performance.

Resumo: O estudo objetiva desenvolver e testar um modelo que enfatiza o relacionamento da intenção empreendedora e capacidade gerencial no desempenho de propriedades leiteiras. O artigo também examina o efeito do desempenho atual na expectativa de desempenho futuro e no planejamento sucessório das fazendas. A amostra consistiu em 158 produtores de leite do Paraná e do Rio Grande do Sul, realizada em 2017. Para validar o modelo e testar as hipóteses, utilizou-se o procedimento estatístico Path Analysis (Análise de Caminhos). Os resultados mostram que, entre as dimensões da orientação empreendedora, a inovatividade tem mais impacto no desempenho e na capacidade gerencial. A capacidade gerencial não é significativamente relacionada ao desempenho atual das fazendas leiteiras, mas sim à expectativa de desempenho, que, por sua vez, tem impacto significativo no planejamento sucessório das fazendas. A idade dos agricultores modera as relações, especialmente, entre inovatividade, proatividade e capacidade gerencial no desempenho das fazendas.

Palavras-chave: orientação empreendedora, capacidade gerencial, produtores de leite, desempenho.

\section{Introduction}

The performance of farms and their continuity in the most varied activities depend on a complex set of variables, whose origin may be external and/or internal to the farms (Borges et al., 2015; Cella, 2002; Lopes et al., 2004; Oliveira et al., 2007; Vivan, 2002). This study is based on an internal perspective and conceptualizes that farmers' entrepreneurial orientation (EO) and managerial capacity (MC) are necessary elements to deal with the complexity and the multifaceted environment in which they operate (Gellynck et al., 2015; McElwee, 2006). 
Although recognizing the importance of entrepreneurial orientation and managerial capacity for business performance, literature on agricultural economics usually pays little attention to exploring the effects of these phenomena on agricultural performance (Gellynck et al., 2015; McElwee, 2006). However, dairy farmers have been highly encouraged to see themselves as businessmen with an entrepreneurial spirit (Phillipson et al., 2004) and to manage their properties as a real enterprise (Ondersteijn et al., 2006). This trend seems to come from the managerial practice and the knowledge brought forward by the management of urban enterprises, showing that both, being entrepreneurial (or being entrepreneurially oriented) (Bucktowar et al., 2015, Covin \& Slevin 1991, Gupta \& Batra, 2016; Miller, 1983; Wiklund \& Shepherd, 2005; Zahra \& Covin, 1995), and being able to run a business (Rougoor et al., 1998, Solano et al., 2006, Teixeira \& Vale, 2008; Vivan, 2002) are key elements to have good performance in agriculture.

Although there have been studies in the rural setting devoted to understanding the relationship between EO and MC on farm's performance, (Bergevoet et al., 2004; Billington \& Cannon, 2010; Burhanuddin et al., 2013; Galloway \& Mochrie, 2005; Grande et al., 2011; Kahan, 2012; Micheels \& Gow, 2008; Patel et al., 2014; Raina et al., 2016; Veidal \& Flaten, 2014; Verhees et al., 2011; Zellweger et al., 2010), most of them analyze the impact of each of these dimensions in an isolated way on the performance. In addition to this, most of the studies use perception measures for capturing performance and the other dimensions analyzed in this study (Bergevoet et al., 2004, Micheels \& Gow, 2008, Raina et al., 2016).

The farming activity addressed in this article is dairy production. In the Brazilian agribusiness, the dairy production chain is one of the important axes that contributes to the formation and composition of GDP, but it is also the support activity for a large number of predominantly small-scale family farmers (Holanda Junior \& Campos, 2003; Travassos et al., 2016). Given the importance of this activity in Brazil, we aim to establish some integrated causal linkages between EO and MC of dairy farms with their real productive and economic performance, as well as with performance expectations and with their succession's plan organization.

Our research question focuses and reads as: Do entrepreneurial orientation and managerial capacity impact dairy farming's actual performance and their future expectations?

In order to answer this question, we are going to use the EO theoretical foundation proposed by Miller (1983) and collaborators, who see it as a practice focused on innovativity, proactivity, and risk-takings (Baker \& Sinkula, 2009; Bucktowar et al., 2015; Grande et al., 2011; Kwak et al., 2013; Verhees et al., 2008). On the other hand, the MC refers to the administrative abilities to plan and perform relevant acts in areas such as financial management, operations, and market relations (Rougoor et al., 1998; Solano et al., 2006; Teixeira \& Vale, 2008; Vivan, 2002). As the market and productive instability is very present in the dairy activity, it requires a high managerial capacity for reaching productive and marketing efficacy.

It should be noted that the Brazilian literature on economics and rural administration still lacks studies that relate to the central themes of this article. However, there are old and recent studies that show the importance of property management (Albertoni \& Dalmazo, 1991), entrepreneurship (Ehlers, 2007), and succession planning (Costa \& Ralisch, 2013) for the development of agriculture businesses. Thus, in this article, these themes are empirically related in a hierarchical model where EO and MC are considered antecedents of farm performance and future succession planning.

After a section where the main hypotheses are developed, the study gets unfolded presenting the sample basis that allows testing the theoretical model in two distinct samples of dairy farmers in Brazil. Finally, the main conclusions are drawn from the results. 


\section{Framework and hypotheses}

In the conceptual model of this study, we are going to use the dimensions proposed by Miller (1983) on entrepreneurial orientation and by Rougoor et al. (1998) regarding managerial capacity. The EO perspective in the rural sector, specifically in dairy activity can be related to several actions and attitudes that the dairy farmers bring forward and practices that they use in their properties.

EO involves a willingness to innovate in order to rejuvenate the market offerings, to be more proactive than competitors concerning new market opportunities, and to take risks at experimenting with new and uncertain services, products, and markets (Wiklund \& Shepherd, 2005). In the rural setting, Verhees et al. (2011, 2012), showed that the EO had a positive influence on farming performance. As for innovativity, Madalena (2001) emphasizes that the technological level of the farming system - innovativity component of the agricultural properties - must be based on high levels of technical expertise for installations, machines, and equipment. In addition, the innovativity in dairy activity is evidenced when the farmer makes innovative moves. For example, through the incorporation of more nutritious pastures, more modern sanitary practices, more effective reproductive techniques, and the use of more modern machinery and equipment. The search for innovativity is a condition to overcome barriers that hinder or limit the productive potential of the activity. Proactivity is related to the farmer's anticipation, as manager of the activity, about the microenvironment surrounding the rural property and the general scenario of the activity (Canever et al., 2011). Thus, the search for management practices that aim to help increase animal productivity, increase the productivity of the system, better employment of rural areas, cost reduction (without getting the system damaged), and planning based on future possibilities, in a proactive way and constant evaluation, is a reflection of proactive behavior of the property manager. In addition, in dairy activity, anticipation and monitoring of the environment might occur through constant updating of the farmer, searching for information, and participation in activities related to the sector. Participation in courses, workshops, lectures, and other opportunities for sharing experiences and searching for knowledge, are attitudes of the rural manager that characterize the interest for updating, development of new abilities and capacities that directly impact the performance on dairy activity.

Risk-taking, the third component of the entrepreneurial orientation, according to Matsuno et al. (2002) is the willingness to allocate resources into projects with reasonable chances of failures that could be costly. In the rural setting, most decisions are made under production, market, financial and human uncertainties. However, it is also important to recognize that a successful farm takes risks consistent with its goals and capabilities (Barbieri \& Mahoney, 2009; Clark, 2009). One way of reducing risk is by diversifying or making the farm multifunctional, but the implementation of these strategies is in itself risky, because it depends on the unknown future and on how much the farmer is prepared to act (Dargan \& Shucksmith, 2008).

Farmers who engage in new farming practices -still unknown by most the other farmers are likely to take moderate risks. Such practices in the scope of dairy farming may be linked to the use of medicines, machinery, and equipment not well established in the market and the use of new products to preserve milk's quality. In addition, a lesser or greater likelihood for the farmer to spend financial resources for investments and improvements may characterize the risk-taking behavior of farmers. The impact of risk-taking on the performance of a dairy activity is realized through the accomplishment of opportunities in practices applied on a dayto-day basis of the farm. Thus, the fact that the farmer takes risks, for example, via certain moves or by alternative management in the production system might be a fundamental tool 
to assist in the growth and development of the property. Based on these arguments, the first three hypotheses of the study are as follows:

H1: Innovativity positively affects the performance of dairy farms.

H2: Proactivity positively affects the performance of dairy farms.

H3: Risk-taking positively affects the performance of dairy farms.

Managers and properties more entrepreneurially oriented may have a differentiated manager and managerial process (Barreto \& Nascif, 2014; Grande et al., 2011; Griffith et al., 2006; Knight 1997; McElwee 2006; Patel et al., 2014; Teece, 2009). In other words, the effects of EO on performance are mediated by $\mathrm{MC}$, as a consequence of the better management enforced by the EO behavior. The final result is a better performance. However, for the mediation to occur, first, the constitutive elements of EO (Innovativity, Proactivity, and Risk-taking) are assumed, according to Teece (2009) and Todorovic et al. (2015), of impacting the MC. These elements give scope for the creation of the next hypotheses of this study, which refer to the influence of the EO dimensions on the MC of the farmers:

H4: Innovativity positively affects the MC of dairy farmers.

H5: Proactivity positively affects the MC of dairy farmers.

H6: Risk-taking positively affects the MC of dairy farmers.

The assumption is that $\mathrm{MC}$ enables more efficient allocation of resources and organizational effectiveness (Carvalho, 2013; Rougoor et al., 1998). The majority of dairy farmers in Brazil are categorized as small farms, who use family labor and manage their activities based on experience and tradition, without formal training in administration (Borges et al., 2015). But, as farms develop and expand, they tend to use proportionally less family labor, requiring outside help. However, both small and large producers do not differ so much from each other concerning MC as pointed out by Alves (2004).

According to Rougoor et al. (1998), MC comprises the managers' skills and abilities in the process of organizing, controlling, and planning their organizations. It is understood as the best way to act, in the face of a given situation, at the most convenient moment and with the most appropriate tools. Properties with production systems and similar economic and institutional environments, but with different performances, generally have differences in management (Perea et al., 2014). The difference may lie in the support of consultants specialized in management, the time spent in processing the results, the quality of the planning, and data control (Lopes et al., 2016; Rougoor et al., 1998; Tanure et al., 2009). In other words, the differences might be caused by the managerial capacity existing on the farm. Thus, the seventh hypothesis relates $\mathrm{MC}$ to performance:

H7: Dairy farmers' MC positively affects the performance of dairy farms.

The farm performance is a key factor for the decision to move forward with the farm ownership. The implementation of new improvements is also dependent on performance (Bhuyan and Postel, 2009; Callado et al., 2007; Clark and Jones 2007; Gloy et al.,2002; Groot et al., 2006; Jan et al., 2012; Offerman \& Nieberg, 2000; Ondersteijn et al., 2006). Therefore, the current performance is a predictor of future performance (Banker et al., 2000; Callado et al., 2007; Dolman et al., 2014; Gloy et al., 2002; Ortega et al., 2007; Passel et al., 2007), and the eighth hypothesis relates the current performance to the performance expectation:

H8: The farm's current performance positively impacts the future performance expectation.

The succession process is another key aspect in agriculture nowadays (Brumer et al., 2000; Cavicchioli et al., 2015; Kerbler, 2012; Man, 2007; Mishra et al., 2010; Mishra \& El-Osta, 2007; Ochoa et al., 2007). There is evidence that those who plan the succession process have larger productive scales (Man, 2007; Ochoa et al., 2007), higher incomes (Cavicchioli et al., 2015), higher 
feasibility (Brumer et al., 2000; Ochoa et al., 2007) and are better organized administratively (Barclay et al., 2005; Man, 2007; Panno, 2016). All these factors point to the conclusion that farms with higher performances are more likely to anticipate the organization of the succession process. In addition, there is also evidence that properties with higher performance expectations induce producers to initiate a process of succession organization (Brumer et al., 2000). Thus, the following two hypotheses relate the successful organization of the farms to performance and performance expectation.

H9: The organization of the succession process of dairy farms is positively affected by its current performance.

H10: The organization of the succession process on the dairy farms is positively affected by its performance expectation.

Our final hypothesis concerns the effects of social and economic characteristics of farms and farmers on the relationship between the variables of the theoretical model presented in Figure 1. Unlike Rougoor et al. (1998), who conceptualized MC associated with age, level of schooling, and experience in the activity, in this study these are control variables. Thus, it is expected that groups of farmers from different regions, at different ages, schooling, and level of specialization in the dairy activity present models with different adjustments.

H11: Groups of farms/farmers with different socio-demographic characteristics produce distinct models from the general one.

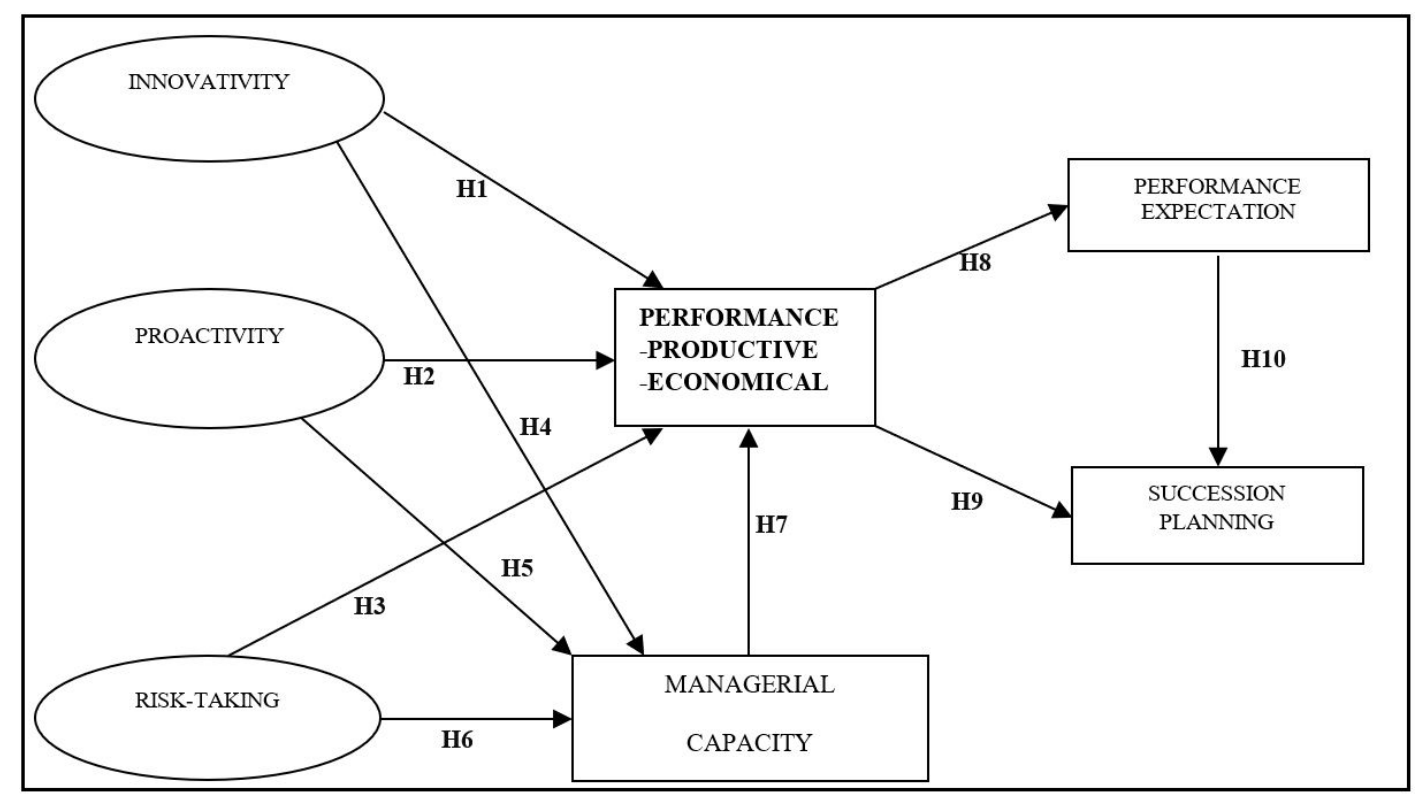

Figure 1. Conceptual model and study hypotheses

\section{Methods and procedures}

\section{Sample aspects and data collection}

A current study is a quantitative approach, a survey conducted with dairy farmers linked to two cooperatives in the South of Brazil (Figure 2). The farmers associated with the first 
cooperative are located in the city of Castro in the state of Paraná, which is recognized as one of the most important farming areas in Brazil. These farmers have specialized in dairy farming since their predecessors migrated from Holland to Brazil in the middle of the last century. The second cooperative is located in the southern part of the state of Rio Grande do Sul, in the region of Pelotas, and it brings together a large group of small dairy farmers. Although having many farmers, this region is not very expressive in terms of dairy farming, when compared to the first one. A total of 158 dairy farmers were interviewed, 105 associated with the Consulate cooperative in Rio Grande do Sul and 53 members of the Castrolanda cooperative in Paraná. We sampled $10 \%$ of the total cooperated farms of each cooperative, stratified in quartiles of size, measured in an average of liters produced per day.

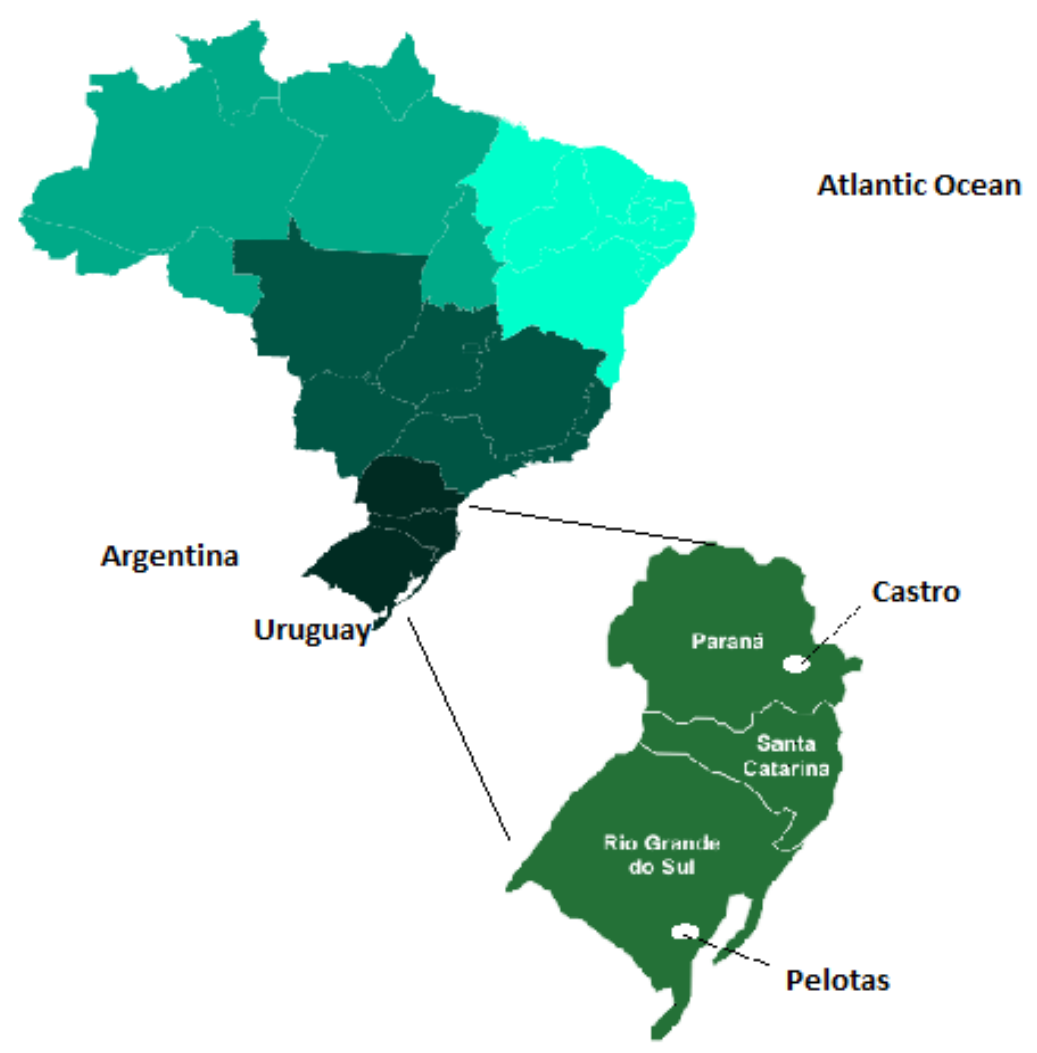

Figure 2. Map showing the sampled regions.

The data were collected through a questionnaire developed to measure the dimensions of the model shown in Figure 1. However, special care was taken to capture the specificities of the dairy farming setting. In order to do this, we first referred to scales available for each dimension in the general literature (Lumpkin \& Dess, 1996; Miller, 1983; Rougoor et al., 1998), but also in the entrepreneurial and managerial literature focused on agriculture (Johansson, 2008; Rougoor et al., 1998; Solano et al., 2006; Verhees et al., 2008). After that, and assisted by a team of experts in dairy production, new items were included to capture the practical facets of each model's dimensions in the context of the dairy activity.

The questionnaire consisted of 22 questions. Section I (referred to rural farmer age, activity experience, and schooling, as well as farm's type of production system, area, production and productivity data, number of animals, characterization of systems, and gross income. 
Section II comprised the measures of innovativity, proactivity, risk-taking, and the management practices adopted in the farm. Each respondent answered the questions through a dichotomous scale (Yes or No) for the various items (practices) constituting the EO and the MC. Section III collected the information about the performance perception, as well as the succession planning of the farm. These questions were answered using a Likert scale of 1 to 5 ( 1 = Totally Disagree and 5 = Totally Agree). Other additional measures of economic performance (price received, monthly income received) and productivity (total liters delivered monthly, average liters produced per cow a day) were obtained directly from the records of the technical department of each cooperative.

\section{Analytical and Measurement Procedures}

The collected data were compiled in statistical software. All analyses were performed using the Stata ${ }^{\circledR}$ IC 12.0 - Data Analysis and Statistical Software program. Initially, we performed the Factorial Analysis to enable the evaluation of each dimension addressed in this study. For the items measured by a dichotomous scale, factorial analysis based on tetrachoric correlation (Lord and Novick, 1967) was used to extract the factors, while for the other scales factorial analysis based on Pearson's correlation was used. All the extracted factors were rotated through the Varimax Rotation and saved to compose the constructs of the theoretical model and to perform the test through path analysis (Hair et al., 2005).

The innovativity of the milk production system was measured through 44 items that totaled innovating practices in nutritional management $\left(8\right.$ items $\left.{ }^{1}\right)$, pasture management (5 items ${ }^{2}$ ), management of milking (7 items ${ }^{3}$ ), reproductive management (13 items ${ }^{4}$ ), and productive operations through the use of innovating machinery and equipment (11 items $\mathrm{s}^{5}$ ). The overall innovative indicator was first obtained by adding the responses (items) on each of the five management. Then, the five scores (for each of the five management systems) were submitted to factorial analysis ${ }^{6}$. The five indicators of innovativity converged into a single factor called INNOVATIVITY (Table 1).

Proactivity measurement items asked if farmers participated in lectures, study groups, workshops, meeting days and sought to update constantly themselves through the information available on websites, magazines, technical material, newspapers, newsletters, quoting programs, technical assistance, and rural extension agencies. Through the factorial analysis, two factors were obtained from the eleven original items, which were named PROSEEK and PROPART (Table 1). PROSEEK factor summarizes the items referring to the proactive attitude of the farmer to seek information, while the PROPART factor summarizes the items referring to the farmer's participation in actions/training activities.

\footnotetext{
1 The questions were whether the farmer provided different diets for the different animal categories, if he used software to plan the diets, if he did the bromatological analysis, if it was used specific diets for each animal category, if automatic feeders were used, etc.

2 Examples of questions: Do you do split and picket rotation? Do you regularly do soil analysis? Do you irrigate pastures? ${ }^{3}$ Examples of questions: Do you control the return of subclinical and / or clinical mastitis? Do you use preventive vaccines for mastitis? Do you use hormones to increase production?

${ }^{4}$ Examples of questions: Do you have an ultrasound scan? Do you use artificial insemination? Do you select the best matrices? Do you do corrective mating? Do you use sexed semen?

${ }^{5}$ Example of questions: Do you use robotic milking? Do you use channeled-like milking? Do you make use of applications and / or software for the herd control and management?

6 The factorial analysis performed was based on Pearson's correlation since each of the five resulting indicators was continuous.
} 
Risk-taking was measured through five dichotomous items (YES or NO), which resulted in two factors. The first factor (FINANCIAL RISK) added two items related to the farmer's intention when taking financial risks in the dairy activity, currently and in the coming years. The second factor (TECHNRISK) grouped three items related to the technological risk in which each farmer is submitted.

The farmers' managerial capacity was evaluated through four important managerial facets in the conduction of the dairy activity. They are: the ability to control the technical information (10 items ${ }^{7}$ ), the farmer's knowledge level to handle the different specific managements of the dairy activity - nutrition, milking, sanity, reproduction $\left(23\right.$ items $\left.{ }^{8}\right)$, the ability to control information $\left(4\right.$ items $^{9}$ ) and the level of external professional support to handle the dairy farm ( 5 items $^{10}$ ). The items of each category were summed and submitted to factorial analysis, which resulted in a single factor called CAP MANAGEMENT.

The dairy farming performance was evaluated through two productive indicators (average of liter/cow/day) and (average of liter/hectare/year). Furthermore, two economic (price received / liter) and (monthly total income) indicators were added for capturing the output generated by the dairy activity. These indicators submitted to factor analysis resulted in a single factorial factor called PERFORMANCE. As for the future performance expectation of the activity it was measured through five items (Table 1) that measured the farmer's hope concerning the productive and economic future of the farm. These questions were based on Verhees et al. (2011) and answered on a Likert scale from 1 (totally disagree) to 5 (strongly agree). After the factorial analysis, the resulting factor FUTUREEXP was constructed from four items. The item "I am optimistic about what I do in my farm" showed no communality higher than 0.4 with the others items, therefore it was excluded from the analysis.

Finally, the existence of succession planning in the farm was measured through six items based on Verhees et al. (2011) and Solano et al. (2003), also measured by Likert scale of 5 points $(1=$ totally disagree, $5=$ totally agree). From six items, three ( wish to get rid of my farm in a few years, my farm is already for sale and I wish to continue working on my farm even after the children leave) were excluded for showing communalities below 0.4 with the other items. The three remaining items collapsed in a factor denominated SUCCESSION.

After the creation of the factors, Path Analysis was carried out, evaluating the adequacy of the theoretical model proposed previously. For this purpose, the CFI index (comparative fit index $>0.95$ ), TLI (Tucker Lewis index $>0.95$ ), SRMR (standardized root mean squared residual $<0.08$ ), RMSEA (root mean squared error of approximation $<0.06$ ), and non-significant chi-square values ( $p>.05$ ), implies that there is no discrepancy between the covariance matrix ascribed in the model with the covariance observed in the data (Hair et al., 2005).

\footnotetext{
7 There were questions related to the control of milk quality, control of the replacement of females, control of individual milk production, among others.

${ }^{8}$ Issues such as: ability to use specific software for management, knowledge about the nutritional requirements of animals, analysis and knowledge about the composition of milk for changes in diet, among other items.

9 The economic management capacity included questions about the collection of information of an economic nature, for example, control of inputs, outputs, economic planning and projections, profitability analysis and feasibility analysis of the activity.

${ }^{10}$ Measured through items such as: The property counts the participation of consultants and external professionals in to support the areas of (a) nutrition, (b) pasture, (c) sanity, (d) economic analysis, herd, among others.
} 
Table 1. Measurement of scale properties

\begin{tabular}{|c|c|c|c|c|}
\hline Factor & Factor Components & $\begin{array}{l}\text { Factorial } \\
\text { Weight }\end{array}$ & $\begin{array}{l}\text { Variance } \\
\text { accumulated } \\
\text { by the } 1 \text { st } \\
\text { factor }(\%)\end{array}$ & a \\
\hline \multirow[t]{5}{*}{ INNOVATIVITY } & Nutrition & 0.79 & 58 & 0.8082 \\
\hline & Pasture & 0.40 & & \\
\hline & Milking & 0.87 & & \\
\hline & Reproductive & 0.79 & & \\
\hline & Machines/Equipment & 0.88 & & \\
\hline \multirow[t]{7}{*}{ PROSEEK } & Sites & 0.76 & 82 & 0.8977 \\
\hline & Magazines & 0.84 & & \\
\hline & Quotation programs & 0.91 & & \\
\hline & TV, newspaper, News on TV & 0.94 & & \\
\hline & Radio & 0.87 & & \\
\hline & Official technical assistance agencies & 0.83 & & \\
\hline & Private technical assistance & 0.82 & & \\
\hline \multirow[t]{4}{*}{ PROPART } & Lectures and conferences & 0.86 & 82 & 0.7912 \\
\hline & Study groups & 0.85 & & \\
\hline & Courses and workshops & 0.91 & & \\
\hline & Meeting days & 0.86 & & \\
\hline \multirow[t]{2}{*}{ FINANCRISK } & Current financial investments & 0.93 & 94 & 0.7634 \\
\hline & Financial investments in the next years & 0.95 & & \\
\hline \multirow[t]{3}{*}{ TECHRISK } & Adopt not well stablished practices & 0.87 & 80 & 0.7337 \\
\hline & Uses new products & 0.84 & & \\
\hline & Starts activities unknown by the majority & 0.87 & & \\
\hline \multirow[t]{4}{*}{ CAPMANAGEMENT } & Ability to control technical information & 0.83 & 68 & 0.8515 \\
\hline & Ability to manage different managements & 0.87 & & \\
\hline & Economical and management abilities & 0.74 & & \\
\hline & $\begin{array}{l}\text { External professional support to manage the } \\
\text { dairy farm }\end{array}$ & 0.85 & & \\
\hline \multirow[t]{4}{*}{ PERFORMANCE } & Annual Average price (R\$/liter) & 0.44 & 56 & 0.7224 \\
\hline & $\begin{array}{l}\text { Gross monthly income generated by the dairy } \\
\text { farm }(R \$)\end{array}$ & 0.89 & & \\
\hline & Liters produced per cow per day (I/cow/ day) & 0.86 & & \\
\hline & $\begin{array}{l}\text { Liters produced per hectare, per year (l/ha/ } \\
\text { year) }\end{array}$ & 0.72 & & \\
\hline \multirow[t]{4}{*}{ FUTUREEXP } & Hopeful as for the success of the activity & 0.84 & 74 & 0.8873 \\
\hline & Hopeful as for the future of the activity & 0.89 & & \\
\hline & Hopeful as for future income growth & 0.86 & & \\
\hline & Optimistic as for future performance & 0.86 & & \\
\hline \multirow[t]{3}{*}{ SUCCESSION } & $\begin{array}{l}\text { Wish to take care of the property to leave it as } \\
\text { an inheritance }\end{array}$ & 0.73 & 65 & 0.7382 \\
\hline & $\begin{array}{l}\text { Have someone to replace him/her in the } \\
\text { future }\end{array}$ & 0.83 & & \\
\hline & Wish to keep working together with kids & 0.86 & & \\
\hline
\end{tabular}

\section{Results and discussion}

The description of the producers and properties that make up the sample (Table 2) shows that the respondents are mostly middle-aged, low-educated men with relatively long 
experience in dairy farming. The vast majority of the sampled properties in both locations use the extensive production system, but with a marked distinction in terms of zootechnical and economic performance. It is noticed that among the sampled localities, there is a greater distinction in terms of characteristics of the properties than in terms of characteristics of the producers.

Table 2. Description of producers and properties.

\begin{tabular}{|c|c|c|c|}
\hline Characteristics & Pelotas & Castro & Total \\
\hline \multicolumn{4}{|l|}{ Characterization - Producers } \\
\hline Age (years) & 48.66 & 43.92 & 47.14 \\
\hline \multicolumn{4}{|l|}{ Gender } \\
\hline Female (\%) & 33 & 22.6 & 29.6 \\
\hline Male (\%) & 67 & 77.4 & 70.4 \\
\hline \multicolumn{4}{|l|}{ Schooling } \\
\hline Grade School (\%) & 72.6 & 29.4 & 58.6 \\
\hline High School (\%) & 14.2 & 51 & 26.1 \\
\hline College $(\%)$ & 13.2 & 19.6 & 15.3 \\
\hline Number of years in dairy activity & 27.47 & 17.66 & 24.29 \\
\hline Dairy activity as main source of income (\%) & 73.3 & 86 & 77.4 \\
\hline \multicolumn{4}{|l|}{ Characterization - Properties } \\
\hline \multicolumn{4}{|l|}{ Type of Production System } \\
\hline Extensive (\%) & 86.8 & 84.6 & 86.1 \\
\hline Semi-confined (\%) & 13.2 & 0 & 8.9 \\
\hline Confined(\%) & 0 & 15.4 & 5.1 \\
\hline Lactating cows & 17.09 & 76.66 & 36.94 \\
\hline Liters produced / cow / day (liters/day) & 11.43 & 17.29 & 13.37 \\
\hline Property extension (hectares) & 49.97 & 67.78 & 55.75 \\
\hline Farm average production (liters/day) & 238.81 & $1,718.96$ & 725.94 \\
\hline Average price received last year ( $\mathrm{R} \$ /$ liter) & 0.8298 & 1.3330 & 0.9975 \\
\hline \multicolumn{4}{|l|}{ Monthly income (last 12 months in $\mathrm{R} \$$ ) } \\
\hline Until R\$1.000,00 De & 22.6 & 0 & 15.3 \\
\hline From $R \$ 1.000$ to $R \$ 2.000,00$ & 18.9 & 0 & 12.7 \\
\hline $\mathrm{R} \$ 2.000 .00$ to $\mathrm{R} \$ 5.000,00$ & 22.6 & 3.9 & 16.6 \\
\hline $\mathrm{R} \$ 5.000 .00$ to $\mathrm{R} \$ 10.0000,00$ & 17.9 & 23.5 & 19.7 \\
\hline $\mathrm{R} \$ 10.000 .00$ to $\mathrm{R} \$ 15.000,00$ & 6.6 & 7.8 & 7 \\
\hline$R \$ 15.0000 .00$ to $R \$ 20.000,00$ & 3.8 & 9.8 & 5.7 \\
\hline Over $\mathrm{R} \$ 20.000,00$ & 7.5 & 54.9 & 22.9 \\
\hline n & 105 & 53 & 158 \\
\hline
\end{tabular}

The correlations between the variables means, and standard deviations are shown in Table 3. As expected, almost all correlations are positive, relatively high, and significant. To test the original (theoretical) model through path analysis, this model was first to run in an attempt to test the hypotheses of the study. The original model presented the Chi-square value of 40.67, which at 12 degrees of freedom produced a highly significant $p$-value $(p=0.000)$, in addition to RMSEA $=0.129, \mathrm{TLI}=0.85, \mathrm{CFI}=0.93$ and the SRMR $=0.06$. Therefore, these indicators together indicate that the initial theoretical model did not fit the data. 
Table 3. Correlation matrix, means, and standard deviations of model constructs.

\begin{tabular}{|c|c|c|c|c|c|c|c|c|c|c|}
\hline & $\begin{array}{l}\frac{c}{\bar{N}} \\
\text { d } \\
\sum\end{array}$ & คิ & 플 & 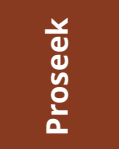 & $\begin{array}{l}\frac{t}{\frac{\pi}{\delta}} \\
\frac{0}{0} \\
\frac{2}{2}\end{array}$ & $\begin{array}{l}\text { 든 } \\
\text { 들 } \\
\text { 표 }\end{array}$ & $\frac{\underline{n}}{\underline{\underline{L}}}$ & 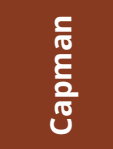 & $\begin{array}{l}E \\
\frac{E}{2} \\
\frac{ \pm}{0} \\
\alpha\end{array}$ & 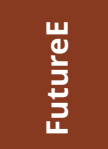 \\
\hline Innovativity & -0.06 & .99 & & & & & & & & \\
\hline Proseek & 0.11 & .41 & $0.31 * *$ & & & & & & & \\
\hline Propart & 0.54 & .43 & $0.50 * *$ & $-0.16^{*}$ & & & & & & \\
\hline Financrisk & 0.60 & .45 & $0.44 * *$ & 0.06 & $0.27 * \star$ & & & & & \\
\hline Technrisk & 0.24 & .45 & $0.33^{* *}$ & $0.15^{\star}$ & $0.31 * *$ & $-0.16 *$ & & & & \\
\hline Capmanagement & 4.46 & 1 & $0.86 * *$ & $0.32 * *$ & $0.58^{* *}$ & $0.45^{* *}$ & $0.29 * *$ & & & \\
\hline Performance & -0.03 & 1.01 & $0.75^{* *}$ & 0.09 & $0.45^{* *}$ & $0.47^{*}$ & $0.16^{*}$ & $0.64 *$ & & \\
\hline FutureExp & -0.03 & 1.02 & $0.36 * *$ & 0.03 & $0.32 * *$ & $0.48^{* *}$ & $0.08^{*}$ & $0.45^{* *}$ & $0.35 * *$ & \\
\hline Succession & -0.002 & 0.99 & $0.19 *$ & -0.02 & 0.14 & $0.29 *$ & -0.06 & $0.21 *$ & $0.24^{*}$ & $0.39 * *$ \\
\hline
\end{tabular}

Note: * $p<0.05 ; * * p<0.01$

Based on modifications of the original model that most contributed to decreasing the discrepancy between the covariance matrix ascribed in the model with the covariance observed in the data, we added two additional paths to the model. The two paths connected FINANCRISK and CAPMANEGEMENT to FUTUREEXP. The standardized coefficients linking each construct to the whole sample and the groups (localities) are shown in Figure 3. Conceptually, the two new estimated parameters make sense, since higher performance expectations are likely to exist when the producers have a higher tendency to take financial risks and when they are more managerially trained. The modified model shows that while there has been a loss of 2 degrees of freedom, this has been more than compensated by the large reduction in the value of ChiSquare statistics. The Chi-square difference test (test D2), is equal to 32.50 which is significant at $p<0.001$. The model overall and goodness of fit measurement are unanimous in indicating the excellent fit of the new model, as seen in the value of Square $\mathrm{Chi}=8.192, \mathrm{df}=10$, RMSEA $=0.000, \mathrm{TLI}=1,001, \mathrm{CFI}=1,000$ and $\mathrm{SRMR}=0.026$.

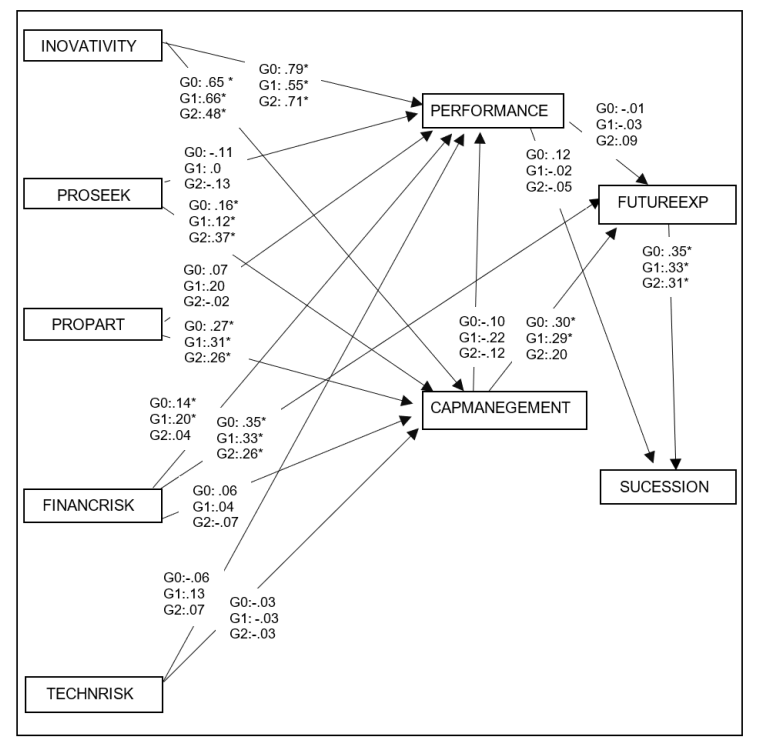

Figure 3. The adjusted model with standardized direct effects for the full sample and by locations (groups). Note: G0 = Complete sample; G1 = Pelotas; G2 = Castro; * Indicates a significant direct path between variables; $p<.05$ 
Before presenting the hypotheses of our study, some elements of the invariance of the parameters estimated between the two locations will be presented to give robustness to the analyzes. In this sense, the invariance test of the structural parameters between the models for the two locations produced a non-significant value ( $\left.x^{2}=32.80, \mathrm{df}=36, \mathrm{p}=0.6214\right)$. So, this result leads us to conclude that the paths between the constructs of the model are equal for both groups. Although the joint test shows that the parameters are equal between the two groups, a further checking through an individual scrutinization (via the Chi-Square difference test), confirm the joint test results that the paths are equal between the groups. The only exception is the path between INNOVATIVITY and CAPMANAGEMENT. This means that the model is valid for both locations and that there is only a small difference in how innovativity influences the managerial capacity, but this difference has not been captured in the overall test of structural parameter differences.

Furthermore, in addition to the test of differences between the structural parameters, the test for the invariance of intercept between groups was significant (chi-square $=70.35, \mathrm{df}=40$, $p=0.002$ ), demonstrating that there are differences of intercepts between groups. Thus, for the sake of interpretability in Table 4, the mean values of each variable are shown. The t-test confirms that the means are significantly different between the two locations. In general, the variables contain higher means for Castro than for Pelotas, and certainly, this is associated with the level of technical development of the activity in each location.

Table 4. t-test for differences of means between the two locations.

\begin{tabular}{|c|c|c|c|c|c|c|c|}
\hline \multirow{2}{*}{ Variable } & \multicolumn{3}{|c|}{ Pelotas } & \multicolumn{3}{|c|}{ Castro } & \multirow{2}{*}{$\mathbf{t}$} \\
\hline & Mean & SD & $\mathbf{N}$ & Mean & SD & $\mathbf{n}$ & \\
\hline Innovativity & -0.47 & 0.78 & 104 & 0.76 & 0.84 & 52 & $-9.05 * \star \star$ \\
\hline Proseek & 0.10 & 0.37 & 105 & 0.13 & 0.48 & 51 & -0.48 \\
\hline Propart & 0.44 & 0.42 & 105 & 0.74 & 0.36 & 51 & $-4.21 * * *$ \\
\hline Financrisk & 0.44 & 0.44 & 105 & 0.92 & 0.26 & 51 & $-7.19 * * *$ \\
\hline Tecnhrisk & 0.29 & 0.43 & 105 & 0.14 & 0.46 & 51 & $1.92 *$ \\
\hline Capmanagement & -0.40 & 0.88 & 100 & 0.77 & 0.72 & 52 & $-8.26 * * *$ \\
\hline Performance & -0.47 & 0.69 & 104 & 0.95 & 0.87 & 49 & $-11.11 * * *$ \\
\hline FutureExp & -0.28 & 1.11 & 101 & 0.46 & 0.53 & 51 & $-4.49 * * *$ \\
\hline Succession & -0.22 & 1.08 & 105 & 0.46 & 0.57 & 51 & $-4.25 * \star \star$ \\
\hline
\end{tabular}

Notes: ${ }^{*} \mathrm{p}<0.10 ;{ }^{* *} \mathrm{p}<0.05 ; * \star * \mathrm{p}<0.01$

As the models are structurally equal between the two groups (as demonstrated above by the invariance test of the structural parameters), the hypotheses are analyzed together. First, we obtained only two significant paths between entrepreneurial orientation and dairy farming performance. Innovativity is by far the highest impact factor, confirming the $\mathrm{H} 1$ hypothesis, and corroborating that it is one of the competitive pillars in agriculture (Gal et al., 2011; Läpple \& Thorne, 2017; McFadden \& Gorman, 2016; Morris et al., 2017). In our case, individual dairy farm performance benefits when innovative management of nutrition, reproduction, pasture, milking, and utilization of farm machinery and equipment are used. If the role of innovation is fundamental to the evolution of agribusiness (Fernandez Cornejo et al., 2007; Läpple \& Thorne, 2017; McFadden, 2016; Smallbone and North, 1999) and its adoption is critically related to the development of agriculture, it becomes clear in the results of this study that this also becomes fundamental in the individual development of dairy farms. Obviously, if performance is affected by innovativity, there are multiple indirect impacts of this on the future persistence of properties, as pointed out by McFadden \& Gorman (2016) and Audretsch et al. (2008). Additionally, we 
verified that the effect of the innovativity on dairy farming performance has only a linear component. When controlling for non-linear effects of innovativity on performance, it presented a non-significant result. So, there is no performance enhancement as the levels of innovativity increase, which contradicts a recurrent idea of the role of innovativity on performance (Läpple \& Thorne, 2017). Thus, for the set of producers in our sample, the more innovative practices are adopted, the higher the performance of the properties, without an apparent maximum or minimum point in the relation.

Taking risks consistently with goals and capabilities seems to be the path for excelling performance (Barbieri \& Mahoney, 2009; Clark, 2009). However, the results of this study are not so consistent with this statement. First, only the financial aspect of risk-taking has been shown to have a significant impact on performance. Taking technical risks does not affect dairy farming performance. In other words, if there are technical uncertainties, it is better to be conservative, maintaining the same behaviors, the usual practices, instead of taking risks and losing everything. Second, although the estimated parameter between FINANCRISK and PERFORMANCE was significant at $p<0.05$ for the whole sample and the dairy farms from Pelotas, the relations were not significant for farms from Castro. But, as presented before, the structural invariability test confirmed that the estimated parameter was the same for both locations, which shows the complexity and no triviality of risk and performance's relation. To a certain degree the results of this study resemble those presented by other authors as Verhees et al. (2008) and Santos et al. (2015), which also found interchangeable interpretations. Therefore, the relation between risk and performance is complex and may depend not only on the risk concept involved (technical or financial) but also on the different productive and economic realities of the producers (Castro or Pelotas), which partially confirms hypothesis 3 of the study.

The literature shows that proactive farmers are pioneers and better prepared to protect themselves from the effects of the threats brought by the competitive environment (Canever et al., 2011). However, in our study, proactivity did not affect performance significantly. Therefore, even for farmers interested in learning and seeking new alternatives for their property, this in itself does not yield better results, which refutes hypothesis 2 of this study.

If being an entrepreneur or having a more entrepreneurially oriented property is one of the conditions for expanding the managerial capabilities of properties, the emphasis should be on innovativity and proactivity. It was these two EO dimensions that had a significant and positive influence on the ability to manage the dairy farm. Additionally, it was also expected that these two EO dimensions could impact performance indirectly, via increases in MC. From the results, we see that this does not happen, since the path between CAPMANAGEMENT and PERFORMANCE is not significant. Therefore, hypothesis 7 was rejected. As in this study, MC was measured through the adoption of practices that facilitate production, reproductive, nutritional, and financial management, it is unknown whether all of these practices are indeed efficient to improve performance. The results of this study do not contradict the studies that advocate MC as fundamental for performance (Lopes et al., 2016; Perea et al., 2014; Rougoor et al., 1998; Tanure et al., 2009), but adds that MC measured as adoption of numerous management practices do not impact performance. Moreover, the innovative feature of the results is the observed direct impact of CAPMANAGEMENT on the future performance expectations (FUTUREEXP) of the farm. Thus, it is clear that the adoption of managerial practices (MC proxy), rather than for the current farming performance, is important, for future performance. Current management practices induce superior performance expectations in the future, corroborating Veloso (1997) when he says that better managerial practices serve to delimit actions directed to consecutive 
years. This works as a chain of means and ends (Gutman, 1982), where the current action is justified and is the reason for future consequences.

Performance expectation (FUTUREEXP) significantly impacted succession planning (SUCCESSION). This was expected as properties with better performance expectations tend to be concerned with the organization of succession, according to Brumer et al. (2000), confirming hypothesis 9. However, surprisingly, the current performance does not significantly impact the planning of the succession process, refuting hypothesis 10 . This result suggests that differentiated current performances do not imply different successional plans. This result is interesting because it contradicts much of what the literature refers to, in which farms with higher performances are more likely to anticipate the organization of the succession process. According to our results, it is future performance expectation and not current performance the trigger for succession planning.

Finally, hypothesis 11 asserted that groups of farmers/farms with different socio-demographic characteristics would produce different models from the general model. The test of this hypothesis was made through the creation of different groups of farmers/farms based on the following socio-demographic variables: schooling, age, years of experience in the activity, and if the dairy activity was the main source of income. Except for this last variable, which generated only two groups (yes and no), all other variables were divided into tertiles, creating three groups. The path models were generated for each group and through the D2 test (Chi-square difference test) the invariability of the structural parameters were checked By the D2 test it was observed that only the groups generated by dividing the sample into age groups (1 st group $\leq 37$ years ( $\mathrm{n}$ $=39)$, 2 nd group of $38-47$ years $(n=41)$ and 3rd group $\geq 48$ years $(n=75)$ ) resulted in models with different structural parameters between groups (Chi-squared $=57.35, \mathrm{df}=32, \mathrm{p}=0.002$ ). This model by age groups generated values of $x^{2}=33.49, \mathrm{GL}=30, \mathrm{RMSEA}=0.050, \mathrm{TLI}=0.980$, $\mathrm{CFI}=0.992$, SRMR $=0.059$, indicating good fit for the proposed dimensions and constructs.

For the sake of space-saving, only the main findings will be described, without presenting the data in tables and figures. Among several relations that showed to be significant between constructs in the different groups, the impacts of INNOVATIVITY and PROSEEK on PERFORMANCE and FUTUREEXP on SUCCESSION are the most relevant. The structural parameters estimated for the first age group (younger) are significantly higher as compared to the other two groups. But diametrically opposed to this first result, we observed that the impact of CAPMANAGEMENT on PERFORMANCE is significantly lower for the 1st age group than for the other two older groups. Finally, the intermediate age group was the one where the risk, both technical and financial (TECHRISK and FINANCRISK) has the greatest impact on performance (PERFORMANCE).

From these relations, it is seen that age is an interesting variable, but what is even more interesting is to evaluate the impacts of the model's construct on the youngest category of farmers. For example, the results show that adherence to innovative practices and technologies yields more intense performance among the younger farmers. Other authors had already warned that there was a negative relation between the farmers 'age and the entrepreneurial behavior, especially in terms of innovativity (Bhosale et al., 2014; Tekale et al., 2013; Çiçek et al., 2008), however, what our study shows is that this category of farmers is more effective in transforming innovativity on performance. Thus, in addition to being more innovative (the means of the innovativity variable was significantly higher for the 1 st group $(G 1=0.08, G 2=$ -0.12 and G3 $=-0.15$ ), the effects of an innovative behavior on performance are greater among younger farmers. If, on the other hand, we observe that the effect of management capacity is negative on performance, it follows that this category tends to focus more on the practical 
actions that impact performance and less on managerial practices, as financial and planning practices, for example.

In Table 5 we summarize the main results of this study, following the hypotheses proposed in the initial model. In general, 7 hypotheses were confirmed, considering the last hypothesis (H11), in which the model differs by socio-demographic characteristics by age groups.

Table 5. Result of the hypothesis test of the global model.

\begin{tabular}{clccl} 
Hypothesis & \multicolumn{1}{c}{ Relation } & $\mathbf{p}$ & Association & \multicolumn{1}{c}{ Result } \\
H1 & INO-> PERF & 0.000 & Positive & Confirmed \\
H2 a & PROSEEK-> PERF & 0.079 & Positive & Not confirmed \\
H2 b & PROAPART->PERF & 0.287 & Positive & Not confirmed \\
H3 a & FINANCRISK->PERF & 0.019 & Positive & Confirmed \\
H3 b & TECHNRISK->PERF & 0.314 & Positive & Not confirmed \\
H4 & INO->CAPMANAGEMENT & 0.000 & Positive & Confirmed \\
H5 a & PROSEEK->CAPMANAGEMENT & 0.000 & Positive & Confirmed \\
H5 b & PROPART->CAPMANAGEMENT & 0.000 & Positive & Confirmed \\
H6 a & FINANCRISK->CAPMANAGEMENT & 0.124 & Positive & Not confirmed \\
H6 b & TECHNRISK->CAPMANAGEMENT & 0.454 & Positive & Not confirmed \\
H7 & CAPMANAGEMENT->PERF & 0.357 & Positive & Not confirmed \\
H8 & PERF->FUTUREEXP & 0.924 & Positive & Not confirmed \\
H9 & PERF->SUCCESSION & 0.129 & Positive & Not confirmed \\
H10 & FUTUREEXP->SUCCESSION & 0.000 & Positive & Confirmed \\
H11 & DEMOGRAPHIC (age) & 0.002 & - & Confirmed \\
\hline
\end{tabular}

\section{Conclusion}

The rural sector coexists with the constant market and productive instabilities, characterizing the environment in which it is inserted as complex and multifaceted. In this study, we argue that the entrepreneurial orientation of the farmers and the management capacity are necessary elements to face this environment and to develop agribusinesses sustainably. Although there is some recognition in the agricultural and livestock community of the importance of EO and MC for rural business development, the literature, especially in agricultural development and economics, pays little attention to exploring the effects of these phenomena, particularly on what concerns the farm's sustainability (Canever et al., 2011; McElwee, 2006). It is recognized that agriculture has differences with other sectors of the economy, but it is necessary for the survival of rural producers to behave as if they were entrepreneurs, adopting innovativity, proactive practices, taking risks, and adopting appropriate management strategies (Ondersteijn et al., 2006, Phillipson et al., 2004, Solano et al., 2006; Verhees et al., 2008). Thus, this study focused on the behavior of agricultural agents (dairy farmers) to study the entrepreneurial and management practices they took to develop their business. Specifically, we tested the impacts of innovativity, proactivity, risk-taking (components of EO), and management capacity on dairy farming performance connecting these dimensions with future performance expectations and succession planning.

The results provide support for the literature on entrepreneurship showing that farmers' EO is positively related to performance. In addition, empirical evidence shows how EO 
dimensions relate to managerial capacity. We conclude that there is strong evidence of the effects of innovative practices and financial risk-taking under the performance levels of dairy farming. Therefore, this reveals that the adoption of innovative practices with a certain level of financial risk is also extremely important for the performance of traditional activities, such as those within the scope of farming. Taking financial risks is associated with both current performance and future performance expectations, showing that the interest in investing as a way of taking advantage of market opportunities is focused on some superior results in the present, but also in the future.

Despite the theoretical assertion that proactive and managerial practices increase farm's performance, our findings did not show significant connections between these dimensions. This leads us to think that the impacts of proactive and management practices may contribute to the performance of farms in a time-lagged way. That is, in dairy farming, the adoption of proactive and managerial practices takes a certain amount of time to mature and result in performance impacts. On the other hand, it might be that the adoption of proactive and managerial practices alone may not be enough to drive the properties to perform better. Hence, having more or less proactive and managerial practices despite being a farm qualifier, is incapable of influencing its performance .

Agriculture realities are heterogeneous (scale, availability of infrastructure, educational level of the farmers, among others) and consequently the level of development of rural activities may depend on constraints imposed by these realities. For example, for the farms analyzed in this study the farmers' age yields heterogeneous groups. This study contributes to recognize the importance of the age of farmers for the effectiveness of establishing development strategies and future actions in the dairy sector. If the goal is to have superior performance and prospects for continuity, it is critical to focus on the younger producers. This is because innovativeness and proactivity most strongly impact the performance led by this category of farmers. On the other hand, it is also in this category that management capacity negatively impacts performance. Based on the information that there is consistent aging of the rural population in Brazil (Anjos \& Caldas, 2005; Camarano \& Abramovay, 1999; Froehlich et al., 2011; Waquil, 2013), such findings constitute a valuable contribution to the debate of rural business sustainability.

The present work is subject to several limitations. First, the use of a non-probabilistic sample of milk producers limits the generalization of the results. Carrying out future research using a representative sample and covering other agricultural activities in Brazil and other countries can contribute to improving the understanding and validation of the results.

Second, it is important to consider other EO dimensions, such as the quest for autonomy and competitiveness, which might provide new theoretical and practical insights. In addition, it is important to consider that this study is cross-sectional and, therefore, has limitations to capture the dynamic effects that longitudinal studies make possible. Moreover, there are other possibilities of deepening the research, for example, by examining the moderating effects on the hypotheses brought by other factors, such as the size of the property and strategic posture (whether conventional or organic), among others.

Third, given the innovative way in which the main construct was measured, based on the adoption of entrepreneurial-oriented and management practices, it is recommended to reevaluate those practices with the purpose of better validate them. In addition, a critical analysis of practices that confer managerial capacity is also recommended. In the study, we assumed that the more managerial practices are adopted, the more skilled the farmers will be, however, this relation may not be so direct. 
Finally, considering that EO and management capacity imply not only the adoption of technical and practical elements, the configuration of a social environment that is temporally related to factors such as succession and the perspective of business continuity in the family, this study provided an analysis of these concepts in the Brazilian agricultural setting. In general, these concepts are studied in the industrial sector, with rare exceptions in the agricultural sector (Gellynck et al., 2015; Reis Neto et al., 2016). The rural sector is well recognized as different from the industrial environment because they are centered on the farmer's family, where entrepreneurial and management practices are incorporated daily without major formalizations.

Testing the applicability of these concepts in the Brazilian dairy sector, in which the great majority of producers are small family farmers, is of great value. Property management, entrepreneurship, and family succession are already considered important themes in rural literature (Ehlers, 2007; Costa \& Ralisch, 2013). Taking advantage of this, this article highlights the effects of innovative practices, financial risk-taking, and the interaction of the farmers' age in the development of rural businesses.

\section{References}

Albertoni, L. A., \& Dalmazo, N. L. (1991). Análise plurianual de propriedades do Oeste Catarinense monitoradas pelo método "gestão agrícola". Revista Economia e Sociologia Rural, 29(3), 259-268.

Alves, E. (2004). Retorno à escala e mercado competitivo: teoria e evidências empíricas. Revista Agronegócio, 2(3), 311-334.

Anjos, F. S., \& Caldas, N. V. (2005). O futuro ameaçado: o mundo rural face aos desafios da masculinização, do envelhecimento e da desagrarização. Revista Ensaios FEE, 26(1), 661-694.

Audretsch, D. B., Bönte, W., \& Keilbach, M. (2008). Entrepreneurship capital and its impact on knowledge diffusion and economic performance. Journal of Business Venturing, 23, 687-698.

Baker, W. E., \& Sinkula, J. (2009). The Complementary Effects of Market Orientation and Entrepreneurial Orientation on Profitability in Small Businesses. Journal of Small Business Management, 47(4), 443-464.

Banker, R. D., Potter, G., \& Srinivasan, D. (2000). An empirical investigation of an incentive plan that includes nonfinancial performance measures. The Accounting Review, 75(1), 65-92.

Barbieri, C., \& Mahoney, E. (2009). Why is diversification an attractive farm adjustment strategy? Insights from Texas farmers and ranchers. Journal of Rural Studies, 25(1), 58-66.

Barclay, E., Foskey, R., \& Reeve, I. (2005). Farm succession and inheritance: Comparing Australian and international research (Report). Australia: The Institute for Rural Futures, University of New England.

Barreto, J. C., \& Nascif, V. M. J. (2014). O Empreendedor Líder e a Disseminação da Orientação Empreendedora. Revista Brasileira de Gestão de Negócios, 16(51), 180-198.

Bergevoet, R. H. M., Ondersteijn, C. J. M., Saatkamp, H. W., Van Woerkum, C. M. J., \& Huirne, R. B. M. (2004). Entrepreneurial behaviour of dutch dairy farmers under a milk quota system: goals, objectives and attitudes. Agricultural Systems, 80, 1-21.

Bhosale, S. R., Deshmukh, A. N., Godse, S. K., \& Shelake, P. S. (2014). Entrepreneurial behaviour of dairy farmers. Advance Research Journal of Social Science, 5(2), 171-174.

Bhuyan, S., \& Postel, M. (2009, July 26-29). Determinants of organic dairy farm profitability: some evidence from the northeast United States. In Proceedings of the Agricultural \& 
Applied Economics Association's (AAEA) 2009 AAEA \& ACCIJoint Annual Meetings(pp. 1-32). Milwaukee, WI: Agricultural and Applied Economics Association.

Billington, C. S., \& Cannon, A. (2010). Do farmers adopt a strategic planning approach to the management of their businesses? Journal of Farm Management, 14(1), 3-40.

Borges, M. S., Guedes, C., \& Castro, M. C. D. C. (2015). A gestão do empreendimento rural: um estudo a partir de um programa de transferência de tecnologia para pequenos produtores. Revista de Ciências da Administração, 17(43), 141-156.

Brumer, A., Rosas, E. N. L., \& Weisheimer, N. (2000). Juventude rural e divisão do trabalho na unidade de produção familiar. In Anais do Congresso da International Rural Rociology Association (IRSA). Rio de Janeiro: Interações.

Bucktowar, R., Kocak, A. and Padachi, K. (2015). Entrepreneurial orientation, market orientation and networking: impact on innovation and firm performance. Journal of Developmental Entrepreneurship, 20(4), 1550024-1-1550024-22.

Burhanuddin, Harianto, Nurmalina, R., \& Pambudy, R. (2013). The determining factors of entrepreneurial activity in Broiler. Media Peternakan, 36(3), 230-236. http://dx.doi.org/10.5398/ medpet.2013.36.3.230.

Callado, A. A. C., Callado, A. L. C., \& Machado, M. A. V. (2007). Indicadores de desempenho operacional e econômico: um estudo exploratório no contexto do agronegócio. Revista de Negócios, 12(1), 3-15.

Camarano, A. A., \& Abramovay, R. (1999). Êxodo Rural, Envelhecimento e Masculinização no Brasil: Panorama dos últimos cinqüenta anos. In Anais do XXI Encontro Anual da ANPOCS (pp. 1-20). São Paulo: ANPOCS.

Canever, M., Chueca, A. P., \& Pfeilstetter, R. (2011). An Evaluation of Entrepreneurship Orientation within the LEADER+ program in the European Union. Investigaciones Regionales, 22, 155-164.

Carvalho, D. M. (2013). O papel dos recursos no desempenho das empresas: uma aplicação em fazendas produtoras de leite (Dissertação de doutorado). Programa de Pós-graduação em Agronegócios, Centro de Estudos e Pesquisas em Agronegócios, Universidade Federal do Rio Grande do Sul, Porto Alegre.

Cavicchioli, D., Bertoni, D., Tesser, F., \& Friosio, D. G. (2015). What Factors encourage intrafamily farm succession in mountain areas? Mountain Research and Development, 35(2), 152-160.

Cella, D. (2002). Caracterização dos fatores relacionados ao sucesso de um empreendedor rural (Dissertação de mestrado). Escola Superior de Agricultura Luiz de Queiroz, Universidade de São Paulo, Piracicaba.

Çiçek, H., Cevger, Y., \& Tandogan, M. (2008). Socio-economic factors affecting the level of adoption of innovations in dairy cattle enterprises. Ankara Üniversitesi Veteriner Fakültesi, $55,183-187$.

Clark, J. (2009). Entrepreneurship and diversification on English farms: identifying business enterprise characteristics and change processes. Entrepreneurial Regional Development, 21(2), 213-236.

Clark, J., \& Jones, A. (2007). Diversification, networks and rural futures in England. In H. Routledge. Clout. Milton Park Contemporary Rural Geographies: Land, Property and Resources in Britain: Essays in Honour of Richard Munton. Iondon: Routledge Taylor \& Francis Group.

Covin, J. G., \& Slevin, D. P. (1991). A conceptual model of entrepreneurship as firm behavior. Entrepreneurship Theory and Practice, 16(1), 7-25. 
Costa, F. L. M., \& Ralisch, R. (2013). A Juventude Rural do Assentamento Florestan Fernandes no Município de Florestópolis (PR). Revista de Economia Rural, 51(3), 413-432.

Dargan, L., \& Shucksmith, M. (2008). Leader and Innovation. Sociologia Ruralis, 48(3), 274-291.

Dolman, M. A., Sonneveld, M. P. W., Mollenhorst, H., \& Boer, I. J. M. (2014). Benchmarking the economic, environmental and societal performance of Dutch dairy farms aiming at internal recycling of nutrients. Journal of Cleaner Production, 73, 245-252.

Ehlers, E. (2007). Empreendedorismo e conservação ambiental no interior de São Paulo. Revista de Economia Rural, 45(1), 185-203.

Fernandez-Cornejo, J., Nehring, R., Hendricks, C., Southern, M., \& Gregory, A. (2007). Off-farm Income, Technology Adoption and Farm Economic Performance (Economic Research Report, Vol. 36, pp. 1-53). USA: US Department of Agriculture.

Froehlich, J. M., Rauber, C. C., Carpes, R. H., \& Toebe, M. (2011). Êxodo seletivo, masculinização e envelhecimento da população rural na região central do RS. Ciência Rural, 41(9), 1674-1680.

Gal, P. Y. L., Dugué, P., Faure, G., \& Novak, S. (2011). How does research address the design of innovative agricultural production systems at the farm level? A review. Agricultural Systems, 104, 714-728.

Galloway, L., \& Mochrie, R. (2005). The use of ICT in rural firms: a policy-orientated literature review. Info, 7(3), 33-46.

Gellynck, X., Cárdenas, J., Pieniak, Z., \& Verbeke, W. (2015). Association between innovative entrepreneurial orientation, absorptive capacity, and farm business performance. Agribusiness, 31(1), 91-106.

Gloy, B. A., Hyde, J., \& Ladue, E. L. (2002). Dairy Farm Management and Long- Term Farm Financial Performance. Agricultural and Resource Economics Review, 31(2), 233-247.

Grande, J., Madsen, E. L., \& Borch, O.J. (2011). The relationship between resources, entrepreneurial orientation and performance in farm-based ventures. Entrepreneurship \& Regional Development: An International Journal, 23(3-4), 89-111.

Griffith, D. A., Noble, S. M., \& Chen, Q. (2006). The performance implications of entrepreneurial proclivity: A dynamic capabilities approach. Journal of Retailing, 82(1), 51-62.

Groot, J. C. J., Rossing, W. A. H., \& Lantinga, E. A. (2006). Evolution of farm management, nitrogen efficiency and economic performance on Dutch dairy farms reducing external inputs. Livestock Science, 100, 99-110.

Gupta, V. K., \& Batra, S. (2016). Entrepreneurial orientation and firm performance in Indian SMEs: Universal and contingency perspectives. International Small Business Journal, 34(5), 660-682.

Gutman, J. (1982). A means-end chain model based on consumer categorization processes. Journal of Marketing, 46(2), 60-72.

Hair, J. F., Black, W. C., Babin, B. J., Re, A., \& Tatham, R. (2005). Multivariate data analysis. Upper Saddle River: Pearson Prentice Hall.

Holanda Junior, F. I. F., \& Campos, R. T. (2003). Análise técnico-econômica da pecuária leiteira no município de Quixeramobim - estado do Ceará. Revista Economica do Nordeste, 34(4), 621-646.

Jan, P., Dux, D., Lips, M., Alig, M., \& Dumondel, M. (2012). On the link between economic and environmental performance of Swiss dairy farms of the alpine area. The International Journal of Life Cycle Assessment, 17, 706-719. 
Johansson, H. (2008). How can farmer managerial capacity contribute to improved farm performance? A study of dairy farms in Sweden. Acta Agricultura e Scandinavica, Section C - Food Economics, 5(1), 44-61.

Kahan D (2012). Entrepreneurship in farming. Rome: FAO.

Kerbler, B. (2012). Factors affecting farm succession: the case of Slovenia. Agricultural Economics, 58(6), 285-298.

Knight, G. A. (1997). Cross-cultural reliability and validity of a scale to measure firm entrepreneurial orientation. Journal of Business Venturing, 12, 213-225.

Kwak, H., Jaju, A., Puzakova, M., \& Rocereto, J. F. (2013). The connubial relationship between market orientation and entrepreneurial orientation. Journal of Marketing Theory and Practice, 21(2), 141-161.

Läpple, D., \& Thorne, F. (2017). The role of innovation in farm economic performance: generalized propensity score evidence from Irish dairy farms. In: Proceedings of the Agricultural Economics Society's 91st Annual Conference at the Royal Dublin Society in Dublin, Ireland (pp. 1-24). Dublin, Ireland: Journal of Agricultural Economics.

Lopes, M. A., Lima, A. L. R., Carvalho, F. M., Reis, R. P., Santos, I. C., \& Saraiva, F. H. (2004). Controle Gerencial e estudo da rentabilidade de sistemas de produção de leite na região de Lavras (MG). Ciência e Agrotecnologia, 28(4), 883-892.

Lopes, M. A., Moraes, F., Carvalho, F. M., Peres, A. A. C., Bruhn, R. F. P., \& Reis, B. E. M. (2016). Effect of technical indexes on cost-effectiveness in dairy farms participating in the "Balde Cheio" program at different stages of production. Semina: Ciências Agrárias, 37(6), 4235-4242.

Lord, F., \& Novick, M. R. (1967) Statistical theories of mental test scores. Reading: Addison Wesley.

Lumpkin, G. T., \& Dess, G. (1996). Clarifying the entrepreneurial orientation construct and linking it to performance. Academy of Management Review, 21(1), 135-172.

Madalena, F. E. (2001). A vaca econômica. In Anais do $3^{\circ}$ Encontro de Produtores de F1 -Jornada Técnica Sobre Utilização de F1 para produção de leite (pp. 9-16). Juiz de Fora: Embrapa Gado de Leite.

Man, S. (2007). Tracing the process of becoming a farm successor on Swiss family farms. Agriculture and Human Values, 24, 435-443.

Matsuno, K., Mentzer, J. T., \& Ozsomer, A. (2002). The effects of entrepreneurial proclivity and market orientation on business performance. Journal of Marketing, 66(3), 18-32.

McElwee, G. (2006). Farmers as entrepreneurs: developing competitive skills. Journal of Developmental Entrepreneurship, 11(3), 187-206.

McFadden, T. (2016). A description of data sets to determine the innovative diversification capacity of farm households. Data in Brief, 8, 1088-1093.

McFadden, T., \& Gorman, M. (2016). Exploring the concept of farm household innovation capacity in relation to farm diversification in policy context. Journal of Rural Studies, 46, 60-70.

Micheels, E. T., \& Gow, H. R. (2008). Market Orientation, Innovation and Entrepreneurship: An Empirical Examination of the Illinois Beef Industry. The International Food and Agribusiness Management Review, 11(3), 31-56.

Miller, D. (1983). The Correlates of Entrepreneurship in Three Types of Firms. Management Science, 29(7), 770-791. 
Mishra, A. K., \& El-Osta, H. S. (2007). Factors Affecting Succession Decisions in Family Farm Businesses: Evidence from a National Survey. Journal of American Society of Farm Managers and Rural Appraisers, 1(1), 1-10.

Mishra, A. K., El-Osta, H. S., \& Shaik, S. (2010). Succession decisions in US family farm businesses. Journal of Agricultural and Resource Economics, 35(1), 133-152.

Morris, W., Henley, A., \& Dowell, D. (2017). Farm diversification, entrepreneurship and technology adoption: analysis of upland farmers in Wales. Journal of Rural Studies, 53, 132-143.

Ochoa, A. M. A., Oliva, V. C., \& Sáez, C. A. (2007). Explaining farm succession: the impact of farm location and off-farm employment opportunities. Spanish Journal of Agricultural Research, 5(2), 214-225.

Offerman, F., \& Nieberg, H. (2000). Economic performance of organic farms in Europe. Ettlingen, Germany: University of Hohenheim.

Oliveira, A. S., Cunha, D. N. F. V., Campos, J. M. S., Vale, S. L. M. R., \& Assis, A. J. (2007). Identificação e quantificação de indicadores-referência de sistemas de produção de leite. Revista Brasileira de Zootecnia, 36(2), 507-516.

Ondersteijn, C. J. M., Giesen, G. W. J., \& Huirne, R. B. M. (2006). Perceived environmental uncertainty in Dutch dairy farming: The effect of external farm context on strategic choice. Agricultural Systems, 88(2-3), 205-226.

Ortega, A. E., Ayala, E. E., Lopéz, J. B., Martinez, T. C., \& Jordan, M. A. (2007). Small-scale dairy farming in the highlands of central Mexico: technical, economic and social aspects and their impact on poverty. Experimental Agriculture, 43, 241-256.

Panno, F. (2016) Sucessão geracional na Agricultura Familiar: valores, motivações e influências que orientam as decisões dos atores (Dissertação de doutorado). Programa de Pós-graduação em Desenvolvimento Rural, Universidade Federal do Rio Grande do Sul. Porto Alegre.

Passel, S. V., Nevens, F., Mathijs, E., \& Huylenbroeck, G. V. (2007). Measuring farm sustainability and explaining differences in sustainable efficiency. Ecological Economics, 42, 149-161.

Patel, P., Patel, M. M., Badodia, S. K., \& Sharma, P. (2014). Entrepreneurial Behaviour of Dairy farmers. Indian Research Journal of Extension Education, 14(2), 46-49.

Perea, J., Heredero, C. P., Angón, E., Giorgis, A., Barba, C., \& Garcia, A. (2014). Using farmer decision-making profiles and managerial capacity as predictors of farm viability in Argentinean dairy farms (La Pampa). Revista Científica FCV-LUZ, 24(6), 509-517.

Phillipson, J., Gorton, M., Raley, M., \& Moxey, A. (2004). Treating farms as firms? The evolution of farm business support from productionist to entrepreneurial models. Environment and Planning. C, Government \& Policy, 22(1), 31-54.

Raina, V., Bhusan, B., Bakshi, P., \& Khajuria, S. (2016). Entrepreneurial behaviour of dairy farmers. Journal of Animal Research, 6(5), 1-7.

Reis Neto, J. F., Gallego, P. A. M., Souza, C. C., Pedrinho, D. R., Favero, S., \& Mühlen, A. S. R. (2016). Strategic orientations and cooperation of external agents in the innovation process of rural enterprises. Ciência Rural, 46(10), 1878-1884.

Rougoor, C. W., Trip, G., Huirne, R. B. M., \& Renkema, J. A. (1998). How to define and study farmers' management capacity: theory and use in agricultural economics. Agricultural Economics, 18, 261-272. 
Santos, A. C. M. Z., Alves, M. S. P. C., \& Bitencourt, C. C. (2015). Dimensões da orientação empreendedora e o impacto no desempenho de empresas incubadas. Revista de Administração e Contabilidade da Unisinos, 12(3), 242-255.

Smallbone, D., \& North, D. (1999). Innovation and new technology in rural small and mediumsized enterprises: some policy issues. Environment and Planning: Government and Policy, $17,549-566$.

Solano, C., León, H., Pérez, E., \& Herrero, M. (2003). The role of personal information sources on the decision-making process of Costa Rican dairy farmers. Agricultural Systems, 76, 3-18.

Solano, C., León, H., Pérez, E., Tole, L., Fawcett, R. H., \& Herrero, M. (2006). Using farmer decision-making profiles and managerial capacity as predictors of farm management and performance in Costa Rican dairy farms. Agricultural Systems, 88, 395-428.

Tanure, S., Machado, J. A. D., \& Nabinger, C. (2009) Técnicas de Gerenciamento e Suporte à Decisão em Unidades de Produção Agropecuária. In Anais do $47^{\circ}$ Congresso SOBER Sociedade Brasileira de Economia, Administração e Sociologia Rural. Porto Alegre: Revista de Economia e Sociologia Rural.

Teece, D. J. (2009). Dynamic Capabilities and Strategic Management. New York: Oxford University Press.

Teixeira, M. B., \& Vale, S. M. R. L. (2008). Estilos gerenciais e objetivos de agricultores da região norte do estado do Espírito Santo. Organizações Rurais \& Agroindustriais, 10(2), 226-238.

Tekale, V. S., Bhalekar, D. N., \& Shaikh, J. I. (2013). Entrepreneurial behaviour of dairy farmers. International Journal of Agricultural Education and Extension, 9, 32-36.

Todorovic, Z. W., Todorovic, D., \& Ma, J. (2015). Corporate entrepreneurship and entrepreneurial orientation in corporate environment: a discussion. Academy of Entrepreneurship Journal, 21(1), 82-92.

Travassos, G. F., Sobreira, D. B., Gomes, A. P., \& Carneiro, A. V. (2016). Determinantes da eficiência técnica dos produtores de leite da mesorregião da Zona da Mata-MG. Revista de Economia e Agronegócio, 13, 63-92.

Veidal, A., \& Flaten, O. (2014). Entrepreneurial orientation and farm business performance: The moderating role of on-farm diversification and location. Entrepreneurship and Innovation, 15(2), 101-112.

Veloso, R. F. (1997). Planejamento e gerência de fazenda: princípios básicos para avaliação de sistemas agrossilvipastoris nos cerrados. Cadernos de Ciência \& Tecnologia, 14(1), 155-177.

Verhees, F.J. H. M., Klopcic, M., \& Kuipers, A. (2008) Entrepreneurial Proclivity and the Performance of Farms: The Cases Of Dutch and Slovenian Farmers. In Proceedings of the 12th EAAE Congress'People, Food and Environments: Global Trends and European Strategies. Gent, Belgium: International Journal of Entrepreneurship and Small Business.

Verhees, F. J. H. M., Lans, T., \& Verstegen, J. A. A. M. (2011). Entrepreneurial Proclivity, Market Orientation and Performance of Dutch Farmers and Horticultural growers. In: Proceedings of the 12th EAAE Congress Change and Uncertainty Challenges for Agriculture, Food and Natural Resources. Zurich, Switzerland: International Journal of Entrepreneurship and Small Business.

Verhees, F. J. H. M., Lans, T., \& Verseegen, J. A. A. M. (2012). The influence of market and entrepreneurial orientation on strategic marketing choices: the cases of Dutch farmers and horticultural growers. Journal on Chain and Network Science, 12(2), 167-180. 
Vivan, A. M. (2002). Análise de eficiência técnica e identificação do perfil gerencial de produtores rurais (Dissertação de mestrado). Programa de Pós-graduação em Administração, Universidade Federal de Lavras, Lavras.

Waquil, P. (2013). As especificidades regionais e socioculturais da pobreza rural na região sul do Brasil. In C. M. B. Tiburcio (Eds.), A nova cara da pobreza rural: desenvolvimento e a questão regional (pp. 355-399). Brasília: IICA.

Wiklund, J., \& Shepherd, D. (2005). Entrepreneurial orientation and small business performance: a configurational approach. Journal of Business Venturing, 20, 71-91.

Zahra, S. A. A., \& Covin, J. G. (1995). Contextual influences on the corporate entrepreneurship performance relationship: a longitudinal analysis. Journal of Business Venturing, 10(1), $43-58$.

Zellweger, T., Mühlebach, C., \& Sieger, P. (2010). How much and what kind of entrepreneurial orientation is needed for family business continuity? In M. Nordqvist and T. Zellweger (Eds.), Transgenerational Entrepreneurship exploring growth and performance in family firms across generations (pp. 195-214). Cheltenham, UK: Edward Elgar Publishing. 